\title{
CANINE VISCERAL LEISHMANIASIS IN BARRA DE GUARATIBA, RIO DE JANEIRO, BRAZIL: ASSESSMENT OF RISK FACTORS
}

\author{
Maria Alice A. CABrerA(1), Adelzon A. PAUlA(2), Luis Antonio B. CAMACHO(1), Mauro Célio A. MARZOCHI(1), Samanta C. XAVIER(2),
} Alba Valéria M. da SILVA(2) \& Ana Maria JANSEN(2)

\begin{abstract}
SUMMARY
Barra de Guaratiba is a coastal area of the city of Rio de Janeiro where American visceral leishmaniasis (AVL) is endemic. Although control measures including killing of dogs and use of insecticides have been applied at this locality, the canine seroprevalence remains at 25\% and during 1995 and 1997 eight autochthonous human cases were notified. In order to evaluate factors related to the increase of the risk for Leishmania (Leishmania) chagasi infection in dogs we have screened 365 dogs by anti-Leishmania immunofluorescent antibody test (IFAT) and captured sandflies in the domestic and peridomestic environment. Some variables related to the infection were assessed by uni- and multivariate analysis. The distance of the residence from the forest border, its altitude and the presence of the opossum Didelphis marsupialis in the backyard, were found predictor factors for $L$. (L.) chagasi infection in dogs in Barra de Guaratiba. The presence of Lutzomyia longipalpis in the peridomestic environment indicates the possibility of appearence of new human cases. Our data also suggest the presence of a sylvatic enzootic cycle at this locality.
\end{abstract}

KEYWORDS: Visceral leishmaniasis; Epidemiology; Reservoirs.

\section{INTRODUCTION}

American visceral leishmaniasis (AVL) is a chronic and wasting disease characterized by the infection of the mononuclear phagocytes by Leishmania (Leishmania) chagasi ${ }^{7,11}$. In Brazil, more than two thousand cases have been reported annually, mostly in the Northeast of the country ${ }^{24}$. In the city of Rio de Janeiro, the disease was first detected in 1977 and the area was considered the most meridional periurban focus in Brazil ${ }^{13,14,19}$.

Barra de Guaratiba is an area of the city of Rio de Janeiro where AVL is endemic. The Brazilian agency for control of infectious diseases (Fundação Nacional de Saúde-FNS), an organ of the Ministry of Health, has performed serologic surveys in canines at this locality. Seropositive dogs by anti-Leishmania Immunofluorescent Antibody Test (IFAT) (titers $\geq 1: 40$ ) have been eliminated and spraying of pyrethroid insecticide has been done inside the houses and yards every six months. Despite those measures, the canine seroprevalence remains $25 \%$ and eight autochthonous human cases were notified during 1995-1996 ${ }^{17}$. This picture suggests that factors related to the transmission and circulation of Leishmania (L.) chagasi among dogs in Barra de Guaratiba have not been taken into consideration in the control strategies of AVL.

Previous entomological studies in the Serra do Mar region, Rio de Janeiro State, showed Lutzomyia longipalpis to be the predominant sandfly in regions higher than 100 meters while $\mathrm{Lu}$. intermedia is most frequent below 100 meters of altitude. Lu. longipalpis has eclectic bloodfeeding behavior: in the domestic environment it feeds on humans, dogs,

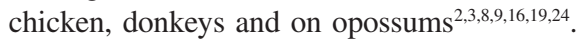

The importance of Didelphis albiventris and D. marsupialis as sylvatic reservoirs of $L$. chagasi has already been suggested ${ }^{2,6,18,20,22}$. In view of its omnivorous diet and its ability to live in the forest as well as in human dwellings, opossums provide the link between the sylvatic and peridomestic environment, capable of infecting and being infected by both sandfly populations ${ }^{18}$.

In this paper, we have evaluated factors likely to be involved in the maintenance and circulation of L. chagasi in Barra de Guaratiba. Thus, variables such as sex and confinement of dogs in backyards, altitude and distance of residences from the forest border and presence of opossums at the peridomicilium were appraised in order to assess the increase of the risk of $L$. chagasi infection in dogs.

\section{MATERIALS AND METHODS}

The area of study: Barra de Guaratiba, with 4000 inhabitants, is a strip of land localized between the Atlantic Ocean and the mountains of Pedra Branca, a massif belonging to Serra do Mar. The climate is tropical, with an

Financial support: FAPERJ.

(1) Escola Nacional de Saúde Pública, FIOCRUZ, Rio de Janeiro, RJ, Brazil:

(2) Laboratório de Biologia de Tripanosomatídeos, Instituto Oswaldo Cruz/FIOCRUZ, Rio de Janeiro, RJ, Brazil.

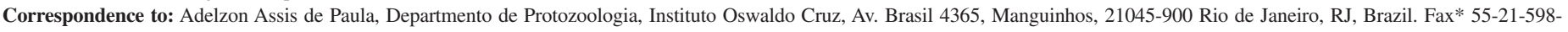
4323; E-mail: adelzon@hotmail.com 


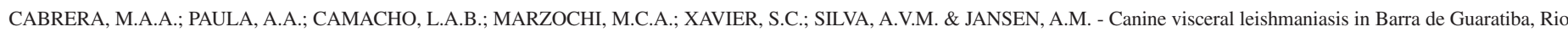
de Janeiro, Brazil: assessment of risk factors. Rev. Inst. Med. trop. S. Paulo, 45(2):79-83, 2003.

annual average temperature of $27.5^{\circ} \mathrm{C}$ and rainfall of $1400 \mathrm{~mm}$. Secondary Atlantic Forest altered by anthropic action covers the mountain slopes. The local population frequently reports the presence of marsupials, armadillos, and small primates. The first AVL human case was notified in 1995, and since then FNS is performing serological surveys in canines in this area.

Capture and identification of sandflies: Aiming to evaluate the transmission potential in the peridomestic environment, CDC light traps were distributed in five selected points across the studied area. The captures were performed once a week during one year (1997-98), regardless of insecticide spraying at the locality. To be eligible as a point of capture, the residences had to have at least one notified human case and/or four seropositive dogs. All points of capture were localized higher than $100 \mathrm{~m}$ and within $100 \mathrm{~m}$ from the forest border. The captured sandflies were identified according to HUDSON \& YOUNG (1985).

Dogs: According to the Centro de Controle de Zoonoses - Rio de Janeiro, the estimated canine population in Barra de Guaratiba is 500 animals (personal communication) and approximately $75 \%(\mathrm{n}=365)$ of them were involved in this study. Only animals of known owners were studied so that data about sex, confinement and presence of opossums at the peridomicilium could be reported. Dogs aging three months or more were bled from the cephalic vein and their sera were examined by antiLeishmania IFAT.

Opossums: Thirty-one opossums were captured in the studied area, both in the forest and inside house-yards. Blood samples were evaluated by hemoculture for Trypanosoma sp and IFAT (serum) using T. cruzi and $L$. chagasi antigens. Marsupials were considered positive when presenting: I) serologic titer $\geq 1: 40$ for $L$. chagasi antigen and negative result for $T$. cruzi antigen and hemoculture or; II) serologic titer $\geq 1: 160$ for $L$. chagasi antigen, whether or not presenting positive serology and culture for T. cruzi. Giemsa stained smears from the liver, spleen, lymph nodes, bone marrow and skin (ear) of all seropositive animals were made. Triturate of liver of one seropositive opossum (titer IFAT: 1:320) was inoculated intraperitoneally in one hamster. Attempts to isolate parasites were made through lymph node aspiration in Vacutainer tubes containing Schnider's insect medium (Sigma Co.).

Laboratory assays: Hemoculture: Blood was seeded in NNN (Nicolle McNeal \& Novy) medium with an overlay of LIT (Liver infusion Triptose), plus $10 \%$ fetal calf serum. Culture tubes were incubated at $27{ }^{\circ} \mathrm{C}$ for 30 days and observed once a week.

Indirect Fluorescent Antibody Test (IFAT) for anti-Leishmania antibody: The reaction was carried out according to the procedures previously described by CAMARGO (1966). The antigens utilized were L. chagasi promastigotes harvested from axenic culture in NNN + LIT media. Rabbit anti-dog IgG fluorescein-labeled conjugate was used (Sigma Co.). Positive and negative dog control sera were obtained from dogs at the Jorge Vaitsmann Veterinary Medicine Institute. Opossum sera were tested by IFAT against two antigens: L. chagasi promastigotes and Trypanosoma cruzi epimastigotes. Sera from experimentally infected opossums were used as positive controls and captivity-born opossum sera, as negative controls. For opossums, an intermediate step (rabbit anti-opossum IgG flurescein-labeled conjugate) was performed according to JANSEN et al. (1985). We have adopted two cut-off points for the reaction in samples from dogs: 1:80 ${ }^{15}$, and 1:40 as established by FNS.
Parasite strains: The following strains of parasites were used in this study: L. chagasi - Kelly strain (MHOM/BR96/RR050) and T. cruzi - G49 strain (MDID/BR/83/G-49).

Data analysis: The following variables were considered: seropositivity, sex and confinement of the dogs, altitude of the house, distance from the forest border and presence of opossums at the peridomicilium. The altitude was measured with an altimeter and the distance from the forest border was estimated.

Data management and analysis were carried out using SPSS software version 7.0. The association of each independent variable with the serological status of dogs was measured by the odds ratio, showing the probability of infection among exposed dogs in comparison to unexposed dogs. The probability of seropositivity to L. chagasi (dependent variable) in relation to the set of independent variables was modeled by logistic regression. Variables entered the model according to the strength of association with infection, and kept according to scientific relevance and statistic significance. The chi-square and Fisher's exact test were utilized to test the statistic significance at a confidence level of $95 \%$. Confounding and interaction among co-variates were assessed through stratified and multivariate analysis.

\section{RESULTS}

Sandflies: Lu. intermedia and Lu. migonei made up $70 \%$ of all captured sandflies (Table 1). Lu. longipalpis was found in two backyards out of five, but even so represented only a small part in proportion to the total of captured sandflies.

Dogs: We have found no significant statistical difference in the seroprevalence levels using both cut-off points: 1:40 (29\% seroprevalence) and 1:80 (25\% seroprevalence). Serological titers ranged from 1:80 to $1: 2560$. Most seropositive dogs presented IFAT titters $\leq$ 1:160 (Fig. 1), but a proportional number of dogs presented titers within the gray zone, i.e., near the cutt-off region, hampering its interpretation.

Opossums: Nine out of thirty-one (29\%) opossums (D. marsupialis) examined in Barra de Guaratiba were seropositive for Leishmania by IFAT, with titers ranging from 1:40 to 1:1280. There was no significant

Table 1

Absolute and relative number of different species of sandflies captured in Barra de Guaratiba, Rio de Janeiro (April/1997 to March/1998)

\begin{tabular}{lcc}
\hline Species & Total & $\%$ \\
\hline Lu. intermedia & 160 & 39.7 \\
Lu. migonei & 122 & 30.3 \\
Lu. edwardsi & 38 & 9.4 \\
Lu. schreiberi & 28 & 6.9 \\
Lu. longipalpis & 26 & 6.4 \\
B. guimaraensi & 18 & 4.5 \\
Lu. quinquefer & 9 & 2.2 \\
Lu. whitmani & 2 & 0.5 \\
\hline Total & 403 & 100 \\
\hline
\end{tabular}

Lu. = Lutzomyia; B. = Brumptomyia 


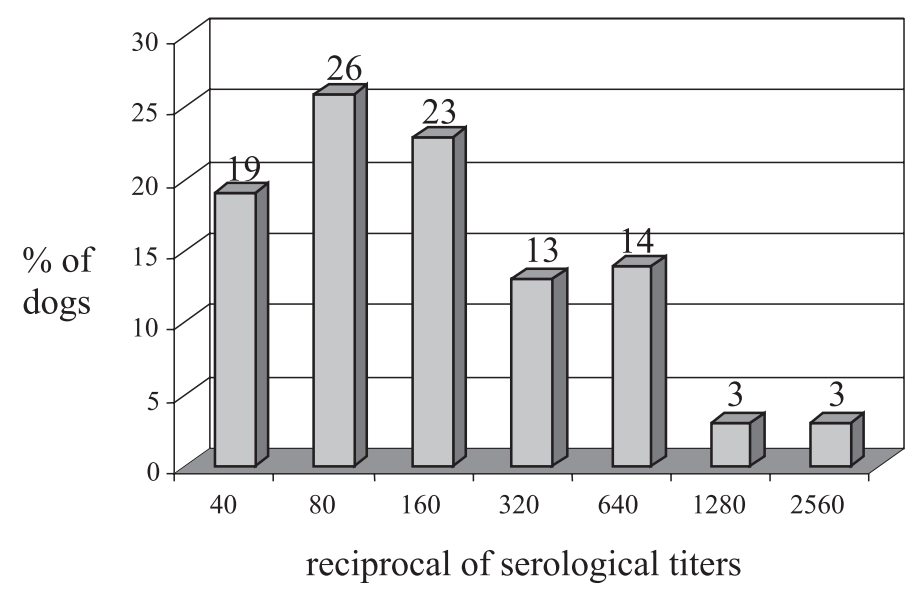

Fig. 1 - Distribution of canine anti-leishmania antibody titers by IFAT among seropositive dogs in Barra de Guaratiba, Rio de Janeiro $(\mathrm{n}=101)$

difference between the seropositivity and the local of capture, i.e., domicilium or peridomicilium. (Fisher's exact test $p=0.528$ ). No clinical signs of AVL were observed in the captured marsupials. All cultures for Leishmania and smears were negative. Nevertheless, amastigote forms were observed in the liver, spleen and bone marrow of an inoculated hamster 90 days after inoculation, which confirmed the Leishmania infection.

Variables: Sex and confinement of dogs - These variables presented weak, non-significant association with L. chagasi infection in dogs (Table 2). Our data show seroprevalence in females (51\%) and males (49\%) to be comparable, which is in accordance to ABRANCHES et al. (1991).

Altitude of the residences - Localization of the house above $100 \mathrm{~m}$ from the sea level, or within $100 \mathrm{~m}$ from the forest seems to increase the probability of seropositivity. Stratified and multivariate analysis disclosed an interaction between the presence of the opossum and altitude of residence (Table 3). According to our data, the probability of dog seropositivity due to opossum presence at the household increased only in houses localized above $100 \mathrm{~m}$. The number of dogs was not sufficient to allow analysis of the association between altitude and Leishmania infection within the stratum distance from the forest.
Distance from the forest border - Dogs living close to the forest represent a 3.49-times risk of infection by L. chagasi when compared to those living 100 meters or more away from the forest. When the other co-variables were assessed together the odds ratio decreased to 2.59.

Presence of opossums in backyards - The 2.6-times increased chance of infection observed in dogs living in houses where the presence of opossums was reported, associated with the occurrence of $30 \%$ of infected opossums, suggests that this marsupial could be involved in the transmission of L. chagasi in B. de Guaratiba and may explain, at least in part, the high canine seroprevalence.

\section{DISCUSSION}

The diagnosis of AVL in both humans and dogs, believed to be the main reservoir of $L$. chagasi, remains a difficult task. Current methods rely on clinical criteria, parasite identification in aspirate material and serology. The latter method is widely used in endemic areas as a determinant for the elimination of canines, but lacks sensitivity and frequently underestimates the real incidence of the infection. There is increasing evidence that the level of antibodies, as measured by serological methods using crude antigen preparations such as IFAT,

Table 2

Data on odds ratio values concerning the Leishmania chagasi infection in dogs in Barra de Guaratiba, Rio de Janeiro and possible risk factors. Assessment by univariate analysis

\begin{tabular}{lccc}
\hline Variables & & Odds ratio ( C.I.*) & p value \\
\hline Confinement & Yes & $1.25(0.77-1.98)$ & 0.361 \\
& No & 1.00 & \\
Gender & Male & $0.82(0.51-1.91)$ & 0.399 \\
& Female & 1.00 & \\
Altitude of residence & $>100 \mathrm{~m}$ & $1.70(1.05-2.74)$ & 0.029 \\
Residence distance & $<100 \mathrm{~m}$ & 1.00 & \\
from forest & $<100 \mathrm{~m}$ & $3.49(1.99-6.11)$ & 0.001 \\
Opossum present at yard & Yes & $2.61(1.59-4.31)$ & 0.001 \\
& No & 1.00 & \\
\hline
\end{tabular}

*CI: Confidence Interval

Table 3

Data on the association between the seropositivity of dogs and the presence of opossums and distance from the forest. Stratified analysis: crude and adjusted odds ratio

\begin{tabular}{|c|c|c|c|c|c|c|}
\hline \multirow[b]{2}{*}{ Variable } & \multicolumn{2}{|c|}{ Crude } & \multirow{2}{*}{$\begin{array}{c}\mathrm{p} \\
\text { value }\end{array}$} & \multicolumn{2}{|c|}{ Adjusted } & \multirow{2}{*}{$\begin{array}{c}\mathrm{p} \\
\text { value }\end{array}$} \\
\hline & odds ratio & $\left(\mathrm{CI}^{*}\right)$ & & odds ratio & $(\mathrm{CI})$ & \\
\hline $\begin{array}{l}\text { Residence distance } \\
\text { from forest }(0-100 \mathrm{~m}) \\
\qquad(>100 \mathrm{~m})\end{array}$ & $\begin{array}{c}3.49 \\
1\end{array}$ & $(1.99-6.11)$ & 0.001 & 2.59 & $\begin{array}{c}(1.20-5.56) \\
1\end{array}$ & 0.021 \\
\hline Opossum (0-100 m height) & 1.79 & $(0.95-3.43)$ & 0.007 & 0.92 & $(0.40-2.14)$ & 0.869 \\
\hline Opossum (> $100 \mathrm{~m}$ height) & 4.51 & $(1.95-10.40)$ & 0.010 & 4.79 & $(1.44-15.56)$ & 0.010 \\
\hline
\end{tabular}

*CI: Confidence Interval 


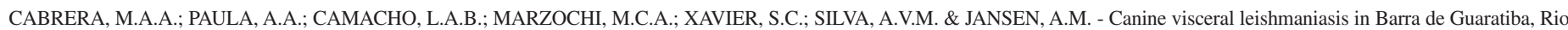
de Janeiro, Brazil: assessment of risk factors. Rev. Inst. Med. trop. S. Paulo, 45(2):79-83, 2003.

should neither be correlated to the parasitic burden nor to the infectious status of dogs from endemic areas. Besides, this method is unable to discriminate dogs capable of controlling the infection. Serological evaluation by IFAT frequently leads to inaccurate results, since low titers can occur due to cross-reactions, resolutive forms of the infection, or even low humoral immunoresponse in the animal ${ }^{4}$.

Regarding the involvement of animal reservoirs, the different causative visceral leishmaniasis species are involved in distinct epidemiological situations. The exact role played by each reservoir, when existing, depends on the species of Leishmania involved. In the New World, the disease occurs in an enzootic form, and canines are believed to be the main urban reservoir. In areas where enzootic leishmaniasis is described, L. chagasi circulates among foxes and opossums. In India, the zoonosis factor is almost absent and the transmission is practically restricted to humans. Thus, man is the only known mammal host of $L$. donovani in this country, conferring an anthroponotic character to the infection. In the Mediterranean region, the infection due to L. infantum is a well represented example of zoonosis, with high canine infection incidence and human infection restricted to children and immunocompromised individuals.

In the studied area, Barra de Guaratiba, constant serological screening has been performed and dogs have been systematically eliminated. Even so, new cases are still occurring since seroconversion in dogs was observed during the period of the study and new human cases have been notified. The link between canine infection and human cases in B. de Guaratiba seems not so direct, seen the high canine seroprevalence (25\%) in contrast to the few human cases verified. To explain the high prevalence of the canine infection despite the continuous killing of dogs, one could suspect that: a) the low sensibility of the diagnostic tool utilized (IFAT), as described by several authors, allows infected false-negative dogs to remain in the area. These animals can represent a source of infection for sandflies, contributing to the maintenance of the level of endemicity observed in B. de Guaratiba and to the appearance of new human cases or that b) sylvatic reservoirs existing in the area help the parasite to maintain itself.

The high absolute and relative occurrence of Lutzomya intermedia and Lu. migonei in Barra de Guaratiba confirms the findings of GOMES (1994), who showed the predominance of these sandflies in unaltered environments. However, the finding of a great number of $\mathrm{Lu}$. intermedia above 100 meters (data not shown) differs from the distribution pattern found in the continental slopes (Serra do Mar) ${ }^{3,19}$, where at this altitude Lu. longipalpis was the predominant species. The high humidity due the proximity of the sea and continuous anthropic action might, at least partially, explain this difference.

Our finding of $29 \%$ of seropositive opossums, in addition to the odds ratio verified with the presence of opossums in the backyards (2.61; $\mathrm{p}=0.05$ ) suggests the existence of a sylvatic cycle of $L$. chagasi in Barra de Guaratiba. The absence of amastigote forms in Giemsa stained smears of skin and lymphoid organs even in the opossums with serological titer 1:320 was also described by other authors in both natural and experimental opossum infection. However, we have detected the parasite by sub-inoculation in hamsters. This result confirms previous studies and reinforces the fact that marsupials can be naturally infected and that even the asymptomatic ones can maintain Leishmania in their organs.
TRAVI et al. (1990) observed that the parasite distribution and consequent vectorial capacity of Didelphis marsupialis varies according to the time and evolution of the infection.

An important aspect of vector-borne diseases is the existence of a particular subset of the host population that is effectively responsible for the maintenance and spreading of the disease ${ }^{26}$. Identifying this host population core is therefore of pivotal importance for the effective control of VL in Barra de Guaratiba. Moreover, our data about risk factors show that the epidemiology of visceral leishmaniasis may be far more complex than hitherto described, since two dicotomic epidemiological features of infection may be observed in Rio de Janeiro: the urbanization of the transmission cycle and the maintenance of a still enzootic cycle.

\section{RESUMO}

\section{Leishmaniose visceral canina em Barra de Guaratiba, Rio de Janeiro, Brasil: avaliação dos fatores de risco}

Barra de Guaratiba é uma região litorânea da cidade do Rio de Janeiro onde a leishmaniose visceral americana é endêmica. Apesar das medidas de controle aplicadas nessa localidade, incluindo sacrifício de cães e borrifação de inseticidas, a soroprevalência canina está estimada em 25\% e durante 1995 e 1997, 8 casos humanos autóctones foram notificados. Para avaliar fatores de risco relacionados com o aumento da infecção por Leishmania (Leishmania) chagasi em cães, nós examinamos 365 cães utilizando a técnica de Imunofluorescência Indireta (IFAT) e capturamos flebótomos em ambientes doméstico e peridoméstico. Algumas variáveis relacionadas à infecção foram avaliadas por análise uni e multivariada. A distância da residência a borda da floresta, sua altitude e presença do gambá Didelphis marsupialis no quintal, foram considerados fatores preditores da infecção por Leishmania (Leishmania) chagasi em cães de Barra de Guaratiba. A presença de Lutzomyia longipalpis em ambiente peridoméstico indica a possibilidade de ocorrência de novos casos humanos. Nossos dados também sugerem a presença de um ciclo enzoótico nessa localidade.

\section{REFERENCES}

1. ABRANCHES, P.; SANTOS-GOMES, G.; RACHAMIM, N. et al. - An experimental model for canine visceral leishmaniasis. Paras. Immunol., 13: 537-550, 1991.

2. AGUIAR, G.M.; VILELA, M.L. \& LIMA, R.B. - Ecology of the sandflies of Itaguaí, an area of cutaneous leishmaniasis in the state of Rio de Janeiro. Food preferences (Diptera, Psychodidae, Phlebotominae). Mem. Inst. Oswaldo Cruz, 82: 583-584, 1987.

3. AGUiAR, G.M.; MEDEIROS, W.M..; DE MARCO, T.S.; SANTOS, S.C. \& GAMBARDELLA, S. - Ecologia dos flebotomíneos da Serra do Mar, Itaguaí, Estado do Rio de Janeiro, Brasil. I. A fauna flebotomínica e prevalência pelo local e tipo de captura (Diptera Psychodidae, Phlebotominae). Cadern. Saúde públ. (Rio de J.), 12: 195-206, 1996.

4. AISA, M.J.; CASTILLEJO, S.; GALLEGO, M. et al. - Diagnostic potential of Western blot analysis of sera from dogs with leishmaniasis in endemic areas and significance of the pattern. Amer. J. trop. Med. Hyg., 58: 154-159, 1998.

5. CAMARGO, M.E. - Fluorescent antibody test for the serodiagnosis of American trypanosomiasis. Technical modification employing preserved culture forms of Trypanosoma cruzi in a slide test. Rev. Inst. Med. trop. S. Paulo, 8: 227-234, 1966. 

de Janeiro, Brazil: assessment of risk factors. Rev. Inst. Med. trop. S. Paulo, 45(2):79-83, 2003.

6. CORREDOR, A.; GALLEGO, J.F.; TESH, R.B. et al. - Epidemiology of visceral leishmaniasis in Colômbia. Amer. J. trop. Med. Hyg., 40: 480-486, 1989.

7. CUNHA, A.M. \& CHAGAS, E. - Nova espécie de protozoário do gênero Leishmania pathogênico para o homem (nota prévia). Hospital (Rio de J.), 11: 5-9, 1937.

8. DEANE, L.M. \& DEANE, M.P. - Observações preliminares sobre a importância comparativa do homem, do cão e da raposa Lycalopex vetulus como reservatório da Leishmania donovani em área endêmica de calazar no Ceará. Hospital (Rio de J.), 48: 61-70, 1955.

9. DEANE, L.M. - Leishmaniose visceral no Brasil. Estudos sobre reservatórios e transmissores realizados no Estado do Ceará. Rio de Janeiro, Serviço Nacional de Educação Sanitária, 1956

10. GOMES, A.C. - Sand fly vectorial ecology in the state of São Paulo. Mem. Inst. Oswaldo Cruz, 89: 457-460, 1994.

11. HERWALDT, B.L. - Leishmaniasis. Lancet, 354: 1191-1199, 1999.

12. HUDSON, J.E. \& YOUNG, D.G. - New records of phlebotomines, leishmaniasis an mosquitoes from Suriname. Trans. roy. Soc. trop. Med. Hyg., 79: 418-419, 1985.

13. JANSEN, A.M.; MORIEARTY, P.L.; CASTRO, B.G. \& DEANE, M.P. - Trypanosoma cruzi in the opossum Didelphis marsupialis: an indirect fluorescent antibody test for the diagnosis and follow-up of natural and experimental infections. Trans. roy. Soc. trop. Med. Hyg., 79: 474-477, 1985.

14. MARZOCHI, M.C.; COUTINHO, S.G.; SOUZA, W.S. et al. - Canine visceral leishmaniasis in Rio de Janeiro, Brazil. Clinical, parasitological, therapeutical and epidemiological findings (1977-1983). Mem. Inst. Oswaldo Cruz, 80: 349-357, 1985 .

15. MARZOCHI, M.C.A.; MARZOCHI, K.B.F. \& CARVALHO, R.W. - Visceral leishmaniasis in Rio de Janeiro, Brazil. Parasit. today, 10: 37-40, 1994.

16. PINELLI, E.; KILLICK-KENDRICK, R.; WAGENAAR, J. et al. - Cellular and humoral immune response in dogs experimentally and naturally infected with Leishmania infantum. Infect. Immun., 62: 229-235, 1994.

17. QUINNELL, R.J.; DYE, C. \& SHAW, J.J. - Host preferences of the phlebotomine sandfly Lutzomyia longipalpis in Amazonian Brazil. Med. vet. Entomol., 6: 195-200, 1992.
18. ROÇADO, A.L. - Leishmaniose visceral Leishmania (Leishmania) chagasi Cunha \& Chagas, 1937 em humanos e caninos na região de Guaratiba, Rio de Janeiro. Rio de Janeiro, 1997. (Dissertação de Mestrado - Universidade Federal Rural do Rio de Janeiro, Seropédica)

19. SHERLOCK, I.A.; MIRANDA, J.C.; SADIGURSKY, M. \& GRIMALDI Jr., G.J. Natural infection in the opossum Didelphis albiventris (Marsupialia Didelphidae) with Leishmania donovani, in Brazil. Mem. Inst. Oswaldo Cruz, 79: 511, 1984.

20. SOUZA, M.A.; SABROZA, P.C.; MARZOCHI, M.C.A.; COUTINHO, S.G. \& SOUZA W.J.S. - Leishmaniose visceral no Rio de Janeiro. 1. Flebotomíneos da área de procedência de caso humano autóctone. Mem. Inst. Oswaldo Cruz, 76: 161-168, 1981

21. TESH, R.B. - Control of zoonotic visceral leishmaniasis: is it time to change strategies? Amer. J. trop. Med. Hyg., 52: 287-292, 1995.

22. TRAVI, B.L.; VELEZ, I.D.; BRUTUS, L. et al. - Lutzomyia evansi, an alternate vector of Leishmania chagasi in a Colombian focus of visceral leishmaniasis. Trans. roy. Soc. trop. Med. Hyg., 84: 676-677, 1990.

23. TRAVI, B.L.; JARAMILLO, C.D.; MONTOYA, J. et al. - Didelphis marsupialis, an important reservoir of Trypanosoma (Schizotrypanum) cruzi and Leishmania (Leishmania) chagasi in Colombia. Amer. J. trop. Med. Hyg., 50: 557-565, 1994.

24. TRAVI, B.L.; OSORIO, Y.; GUARIN, N. \& CADENA, H. - Leishmania (Leishmania) chagasi: clinical and parasitological observations in experimentally infected opossum (Didelphis marsupialis), reservoir of New World of visceral leishmaniasis. Exp. Parasit., 88: 73-75, 1998.

25. VIEIRA, J.B.E. \& COELHO, G.E. - Leishmaniose visceral ou calazar: aspectos epidemiológicos e de controle. Rev. Soc. bras. Med. trop., 31 (supl. 2): 85-92, 1998

26. WOOLHOUSE, M.E.J.; DYE, C.; ETARD, J.F. et al. - Heterogeneities in the transmission of infectious agents: implications for the design of control programs. Proc. nat. Acad. Sci. (Wash.), 94: 338-342, 1997.

Received: 27 August 2002

Accepted: 07 February 2003 